\title{
Heteroplasmy in the Control Region of Human Mitochondrial DNA
}

\author{
David Comas, Svante Pääbo, ${ }^{1}$ and Jaume Bertranpetit ${ }^{2}$
}

Laboratori d'Antropologia, Facultat de Biologia, Universitat de Barcelona, 08028 Barcelona, Spain; 'Zoologisches Institut, D-80021, Munich, Germany

\begin{abstract}
The sequencing of a 360-nucleotide segment of the mt DNA control region in a population survey revealed the presence of one individual having heteroplasmy in positions 16,293 ( $A$ and $G$ ) and 16,311 ( $C$ and $T$ ). This case indicates that heteroplasmy in humans may not be as rare as generally believed.
\end{abstract}

$\mathbf{H}$ eteroplasmy in human mitochondrial DNA (mt DNA) has been reported in association with several diseases. ${ }^{(1)}$ However, heteroplasmy has not been described in the control region of the mitochondrial human genome (i.e., the noncoding segment of the mt DNA that includes the origin of replication), despite the hundreds of individuals sequenced worldwide. To our knowledge, only in the case of Tsar Nicholas II, ${ }^{(2)}$ in which DNA was extracted from bone samples buried for $>70$ years, has a putative control region heteroplasmy been reported. In addition, a silent heteroplasmy in the ND6 gene has been followed over five mother-offspring transmissions. ${ }^{(3)}$ Here we report a case of heteroplasmy in an individual with two different transitions in a segment of 360 bp of the human mitochondrial control region (positions $16,024-16,383$ in the reference sequence). ${ }^{(4)}$

\section{MATERIALS AND METHODS}

In a population survey, hair roots of individuals were collected and stored in $95 \%$ ethanol. In each case, one root was introduced in a $1.5-\mathrm{ml}$ sterile microcentrifuge tube containing $0.5 \mathrm{ml}$ of extraction buffer $(10 \mathrm{~mm}$ Tris at $\mathrm{pH} 8.0,10 \mathrm{mM}$ EDTA at pH 8.0, $100 \mathrm{~mm} \mathrm{NaCl}, 2 \%$ SDS, $39 \mathrm{~mm}$ DTT, and $20 \mu \mathrm{g} / \mathrm{ml}$ of proteinase $\mathrm{K}$ ), incubated at $37^{\circ} \mathrm{C}$, and shaken at $180-200 \mathrm{rpm}$ for $\geqslant 3 \mathrm{hr}$. Following a phenol-chloroform extraction, the DNA was concentrated in Centricon-30 tubes and stored at $-20^{\circ} \mathrm{C}$. The amplification of the region was performed using 5-20 $\mu \mathrm{l}$ of the sample in a $50-\mu 1$ reaction volume; the temperature profile for 30 cycles of amplification was $94^{\circ} \mathrm{C}$ for 1 min, $58^{\circ} \mathrm{C}$ for $1 \mathrm{~min}$, and $72^{\circ} \mathrm{C}$ for 1 $\min$. The primers used in this reaction, L15929 (5'-CACCAGTCTTGTAAACCGGA-3') and H16498 (5'-CCTGAAGTAGGAACCAGATG-3'), amplified a segment of $608 \mathrm{bp}$ containing the $360-\mathrm{bp}$ region that was later sequenced. The product of the amplification was purified with GeneClean (BIO 101). The purified amplified product $(7 \mu \mathrm{l})$ was used for sequencing with Sequenase version 2.0 (U.S. Biochemical) following the supplier's recommendations, except that the annealing step was performed by boiling the annealing reaction mixture for 3 min in the presence of NP-40 followed by a short time in a dry-ice/ethanol bath. The two strands were sequenced using the internal primers L15997 (5'CACCATTAGCACCCAAAAGCT- $3^{\prime}$ ) and H16412 (5'-GTGCGGGATATTGATTTCAC-3'). Reaction products were separated by electrophoresis, dried, fixed, and subjected to autoradiography.

\section{RESULTS AND DISCUSSION}

After the first appearance of heteroplasmy in the individual, several sequencing reactions were done with the product of two different digested roots and with three different amplifications of each. $L$ and $H$ strands were sequenced for each case, and the same pattern was observed in all experiments. All of these replicates strengthen the reliability of 
COMAS ET AL.

POS. 16,311

POS. 16,293

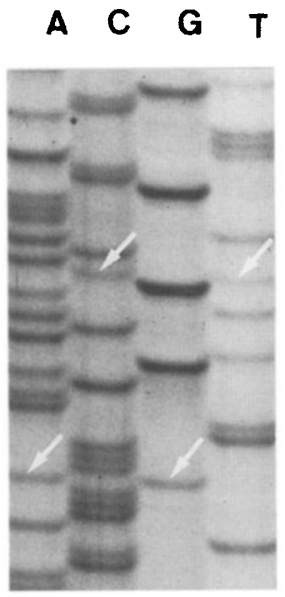

FIGURE 1 Fragment of the sequenced heteroplasmic individual containing positions 16,293 and 16,311 of the mt DNA. Position 16,293 shows a band in lanes $A$ and $G$; position 16,311 shows a band in lanes $C$ and $T$.

the results and decrease the possibility of contamination.

As shown in Figure 1, at position 16,293 , which has no known function and where an A is usually found, two clear bands were observed, corresponding to an $A$ and a $G$, respectively. Also, at position 16,311 , which has no known function either, two bands are observed, corresponding to $\mathrm{T}$ (the most common nucleotide) and $\mathrm{C}$. These two positions have been described as substitutions in population studies and correspond to sites of high substitution rates as determined by phylogenetic means. ${ }^{(5,6)}$ As the samples were collected anonymously, it was not possible to obtain further biological samples from the same individual to undertake further research. Our observation, as well as other reports, ${ }^{(2)}$ indicates that heteroplasmy may not be as rare as is generally believed and thus ambiguities in direct sequencing reactions should be carefully investigated.

The publication costs of this article were defrayed in part by payment of page charges. This article must therefore be hereby marked "advertisement" in accordance with 18 USC section 1734 solely to indicate this fact.

\section{REFERENCES}

1. Wallace, D.C. 1992. Mitochondrial genetics: A paradigm for aging and degen- erative diseases? Science 256: 628-632.

2. Gill, P., P.L. Ivanov, C. Kimpton, R. Piercy, N. Benson, G. Tully, I. Evett, E. Hagelberg, and K. Sullivan. 1994. Identification of the remains of the Romanov family by DNA analysis. Nature Genet. 6: 130-135.

3. Howell, N., S. Halvorson, I. Kubacka, D.A. McCullough, L.A. Bindoff, and D.M. Turnbull. 1992. Mitochondrial gene segregation in mammals: Is the bottleneck always narrow? Hum. Genet. 90: 117-120.

4. Anderson, S., A.T. Bankier, B.G. Barrell, M.H.L. de Bruijn, A.R. Coulson, J. Drouin, I.C. Eperon, D.P. Nierlich, B.A. Roe, F. Sanger, P.H. Schreier, A.J.H. Smith, R. Standen, and I.G. Young. 1981. Sequence and organization of the human mitochondrial genome. Nature 290: 457465.

5. Hasegawa, M., A. Di Rienzo, T.D. Kocher, and A.C. Wilson. 1993. Toward a more accurate time scale for human mitochondrial DNA tree. J. Mol. Evol. 37: 347-354.

6. Wakeley, J. 1993. Substitution rate variation among sites in hypervariable region 1 of human mitochondrial DNA. J. Mol. Evol. 37: 613-623.

Received February 27, 1995; accepted in revised form May 19, 1995. 


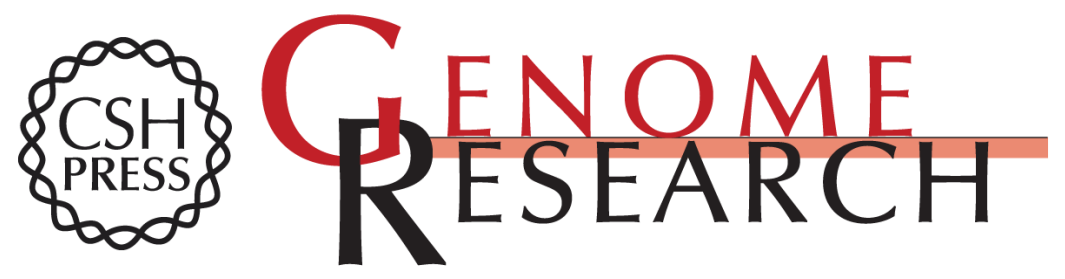

\section{Heteroplasmy in the control region of human mitochondrial DNA.}

D Comas, S Pääbo and J Bertranpetit

Genome Res. 1995 5: 89-90

Access the most recent version at doi:10.1101/gr.5.1.89

$\begin{array}{ll}\text { References } & \text { This article cites } 6 \text { articles, } 1 \text { of which can be accessed free at: } \\ \text { http://genome.cshlp.org/content/5/1/89.full.html\#ref-list-1 }\end{array}$

\section{License}

Email Alerting Receive free email alerts when new articles cite this article - sign up in the box at the Service top right corner of the article or click here.

\section{Affordable, Accurate Sequencing.}

To subscribe to Genome Research go to:

https://genome.cshlp.org/subscriptions 